\title{
JIE
}

JOURNAL OF ISLAMIC EDUCATION

Vol. 7 No. I Mei 2022

P-ISSN 2503-5363; E-ISSN 2528-0465

http://www.ejournal.stitmuhbangil.ac.id/index.php/jie

\section{Implementasi Model Kepemimpinan Transformasional di Pesantren Khozinatul 'Ulum Blora}

\author{
Siti Maesaroh ${ }^{1}$, Hamdan Adib $^{2}$, Novan Ardy Wiyani ${ }^{3}$ \\ 1,2,3(Universitas Islam Negeri (UIN) Saifuddin Zuhri, Jl. A. Yani No.40A, \\ Purwokerto, Indonesia) \\ *stmae65@gmail.com
}

\begin{tabular}{l}
\hline Informasi Artikel \\
\hline Received: \\
19 October 2021 \\
Accepted: \\
18 November 2021 \\
Published: \\
3 May 2022 \\
Keywords: \\
Transformational, \\
Leadership, Islamic \\
Boarding School.
\end{tabular}

Abstract

The purpose of this research is to find out the implementation of the transformational leadership model at the Khozinatul 'Ulum Blora Islamic Boarding School by utilizing all the components available in the pesantren. The research method used in this research is descriptive qualitative with data collection techniques used, namely documentation, interviews and observations. The results of this study indicate that transformational leadership is based on several principles, namely: The basic principles in transformational leadership at the Khozinatul Ulum Blora Islamic Boarding School are: first, simplification is shown by the clear vision of the Khozinatul 'Ulum Blora Islamic Boarding School. second, motivation, namely kiai in motivating ustadz and students according to their respective responsibilities. third, facilities, namely providing both physical and academic facilities to students and teachers. fourth, innovation, namely being brave and responsible and open to new things as evidenced by changes in the curriculum and collaboration with various parties on the instructions of the kiai. fifth, mobility, namely by doing a systematic division of labor in accordance with the responsibilities of each component. sixth, determination is proven by evaluation as a form of escort and improvement of activities at the Khozinatul 'Ulum Blora Islamic Boarding School.

Tujuan dilaksanakannya penelitian ini yaitu untuk 


\begin{abstract}
mengetahui pelaksanaan model kepemimpinan transformasional di Pesantren Khozinatul 'Ulum Blora dengan memanfaatkan segala komponen yang tersedia di pesantren. Metode penelitian yang digunakan dalam penelitian ini adalah kualitatif deskriptif dengan teknik pengumpulan data yang digunakan yaitu dokumentasi, wawancara dan observasi. Hasil penelitian ini menunjukkan bahwa kepemimpinan transformasional didasari oleh beberapa prinsip yaitu: Prinsip dasar dalam kepemimpinan transformasional di Pesantren Khozinatul Ulum Blora yaitu: pertama, simplifikasi diperlihatkan dengan jelas di visi Pesantren Khozinatul 'Ulum Blora. kedua, motivasi yaitu kiai dalam memotivasi ustadz dan santri sesuai dengan tanggung jawab masing-masing. ketiga, fasilitas, yaitu memberikan fasilitas baik fisik ataupun akademik kepada santri dan juga guru. keempat, inovasi, yaitu berani dan bertanggung jawab dan terbuka akan hal baru dibuktikan dengan adanya perubahan kurikulum dan kerjasama dengan berbagai pihak atas intruksi kiai. kelima, mobilitas yaitu dengan melakukan pembagian kerja secara sistematis sesuai dengan tanggung jawab setiap komponen. keenam, tekad dibuktikan dengan evaluasi sebagai bentuk pengawalan dan perbaikan kegiatandi Pesantren Khozinatul 'Ulum Blora.
\end{abstract}

\title{
I. PENDAhULUAN
}

Arah dan tujuan suatu organisasi atau lembaga masih ditentukan dengan bagiamana seorang pemimpin dalam menjalankan kepemimmpinannya. Meskipun terdapat teori lain yang menyatakan bahwa semangat dan kemampuan anggota menjadi pendorong utama tercapainya tujuan namun pemimpin dengan kharisma yang baik dan memiliki jiwa kepemimpinan menjadi hal yang pasti berperan dalam mencapai tujuan. Setiap pemimpin dalam kepemimpinannya di lembaga yang menjadi tanggung jawabnya memiliki karakteristik yang beragam, ada pemimpin yang menjalankan kepemimpinannya dengan model karismatik, transaksional sampai kepada transformasional.

Model kepemimpinan transformasional menjadi salah satu bentuk kepemimpinan yang saat ini menjadi salah satu hal yang sangat dibutuhkan. 
kepemimpinan transformasional yang diartikan dengan kemampuan pemimpin dalam memberdayakan komunitasnya untuk berkinerja tinggi melalui sentuhan persuasif, psikologis dan edukatif yaitu pendekatan manusiawi dari seorang pemimpin organsiasi (Sagala, 2000). Kepemimpinan ini semakin terasa dibutuhkan dalam kepemimpinan yang terjadi di sebuah pesantren dimana pemimpin yaitu kiai yang menduduki puncak tertinggi di pesantren. kiai sebagai sumber keilmuan di pesantren tidak hanya memiliki tanggung jawab dalam melaksanakan pembelajaran kitab kuning kepada santrinya, kiai juga memiliki tanggung jawab dalam mengarahkan pesantren menuju arah yang hendak dituju (Anggraini \& Anwar, 2021). Bahkan, terdapat beberapa kiai yang memiliki cakupan tanggung jawab yang lebih besar yaitu tidak hanya pada santrinya saja namun langsung terjun ke masyarakat. masyarakat juga demikian menganggap kiai sebagai pelindung karena menjdi sosok yang disegani sehingga kiai memiliki posisi sebagai pelindung, pendidik, motivator, pengayom dalam masyarakat (Purnomo, 2020).

Tanggung jawab kiai dalam posisinya sebagai pemimpin sebuah pesantren biasanya menampilkan ketatnya pengawasan dan kontrol bagi santrinya dalam mengurus pesantren, meskipun biasanya di bantu dengan beberapa pengurus yang sering kali berperan sebagai eksekutor kebijakan yang diberikan oleh kiai. tidak jarang pengurus memberikan tindakan bagi santri yang melanggar peraturan yang telah dibuat dan disahkan oleh kiai (Takdir, 2018).

Posisi kiai sebagai pemimpin sekaligus controller juga terjadi di pesantren Khozinatul 'Ulum Blora, namun kiai tidak hanya sebagai sosok yang mengatur sendiri, terdapat wakil pengasuh yang terdiri dari beberapa putra kiai (gus dan ning) dan pembina yang terdiri dari beberapa ustadz yang ikut mengajar di pesantren Khozinatul 'Ulum Blora. kepemimpinan yang diberikan oleh kiai di pesantren ini juga memiliki karakteristik dimana dalam penelitian kali ini ditujukan untuk melihat karakteristik yang kepemimpinan transformasional yang ada di pesantren Khozinatul 'Ulum Blora.

Sebenarnya penelitian yang serupa juga telah dilakukan oleh Remiswal dkk, dimana dalam penelitiannya melihat model kepemimpinan yang terdapat di pesantren secara kolektif dan menyimpulkan bahwasannya kepemimpinan 
pesantren saat ini ialah individual-kolektif yaitu kepemimpinan yang dilakukan oleh kiai sebagai individual dan dalam kelembagaanya di bawah naungan yayasan yang membutuhkan kolaborasi kolektif (Remiswal, Hasbi, \& Diani, 2020). Penelitian lainnya juga dilakukan oleh Sholihah dan Rahma dimana dalam penelitiannya mereka menyimpulkan terdapat peran pemimpin kolektif dalam pesantren yang berkaitan dengan aktivitas dan tujuan pesantren, dimana hal ini dipengaruhi oleh kiai dan santri sebagai pengaruh internal dan sarana prasarana sebagai faktor eksternal yang mendukung, penghambatnya ialah pandangan masyarakat, kurang terjalinnya komunikasi dan juga rendahnya ketaatan santri (Sholihah \& Rahma, 2020).

Terdapat perbedaan dalam penelitian ini dari penelitian yang telah dilaksanakan dimana dalam penelitian ini meneliti mengenai model kepemimpinan transformasional dalam pesantren tertentu tanpa adanya generalisasi dilihat dari berbagai kebijakan yang diberikan. hal ini penting dilakukan karena dengan mengetahui model kepemimpinan transformasi yang dilakukan bisa digunakan sebagai rujukan oleh pesantren lain yang memiliki karakteristik yang sama atau mendekati sama demi meningkatkan kualitas lembaga yang di pimpinnya.

\section{Kepemimpinan transformasional kajian teoritik}

Kata kepemimpinan muncul dari riset dalam dunia militer, Bernard M Bass dan Ronald E Ringgio dalam Umiarso mendeskripsikan dalam hasil risetnya bahwasannya kepemimpinan menjadi sumber yang sangat kuat dalam pengaturan militer (Umiarso, 2018). Kemudian James McGregor Burns mengembangkannya menjadi kepemimpinan transformasional yang diartikan dengan kemampuan pemimpin dalam memberdayakan komunitasnya untuk berkinerja tinggi melalui sentuhan persuasif, psikologis dan edukatif yaitu pendekatan manusiawi dari seorang pemimpin organsiasi (Sagala, 2000). Maka dalam kepemimpinan transformasional terdapat tiga penekanan utama yaitu adanya sentuhan persuasif, psikologis dan edukatif yang dilakukan oleh pemimpin yang dalam konteks pesantren adalah kiai.

Tiga hal yang menjadi penekanan dalam kepemimpinan transformasional ini menampilkan perilaku pemimpin yang dapat diamati seperti, memiliki pengaruh 
yang diidealkan, memberikan pertimbangan individu, memberikan motivasi dan inspiratif serta memberikan stimulus intelektual (Hutahayan, 2020). Lebih jauh Aini menjelaskan bahwasannya untuk mengetahui seorang pemimpin sudah berhasil melaksanakan kepemimpinan transformasional yaitu dengan memperhatikan beberapa ciri, 1) mengidentifikasi dirinya sebagai agen pembaharuan, 2) memiliki sifat pemberani, 3) mempercayai orang lain, 4) bertindak atas dasar sistem nilai (bukan atas dasar kepentingan individu atau kelompok), 5) memiliki kemampuan untuk menghadapi situasi yang rumit, tidak jelas atau tidak menentu, 6) memiliki visi ke depan (Aini, 2019).

Layaknya model kepemimpinan lainnya di dalam kepemimpinan transformasional juga didasari atas beberapa prinsip yang harus ada di dalamnya yaitu: pertama, simplifikasi, hal ini berkaitan dengan keterampilan mengungkapkan visi secara jelas, kedua, motivasi yaitu kemampuan dalam memberikan energi kepada pengikutnya, ketiga, fasilitas, yaitu kemampuan dalam memfasilitasi pembelajaran, keempat, inovasi, yaitu kemampuan untuk berani dan bertanggung jawab melakukan perubahan, kelima, mobilitas, yaitu optimalisasi sumber daya dalam mencapai visi, keenam, siap siaga, yaitu kemampuan untuk selalu belajar dan terbuka akan paradigma positif, ketuju, tekad, yaitu tekad kuat untuk menyelesaikan dengan baik dan tuntas (Hidayat, 2020).

Transformasi hakikatnya ialah merubah potensi menjadi energi nyata (Khasanah, 2019). Jika makna ini ditarik dalam lembaga pendidikan pesantren, maka dapat dijelaskan bahwasannya transformasi ialah kemampuan yang dimiliki oleh kiai atau pimpinan pesantren untuk merubah potensi lembaganya menjadi energi untuk meningkatkan mutu proses dan hasil yang diinginkan dari santri. mengetahui potensi yang ada dalam pesantren harus diawali dengan pengenalan berbagai elemen dalam diri pesantren dimana Yasid menjelaskan bahwasannya elemen pesantren terdiri dari tiga bagian yaitu pelaku (pengurus pesantren, santri, ustadz dan kiai), perangkat keras (kantor pengurus, aula, perpustakaan, gedung sekolah, pondok, rumah ustadz, rumah kiai dan masjid), dan perangkat lunak (buku, kitab, metode mengajar, evaluasi dan lain sebagainya) (Yasid, 2018). 
Tidak semua pesantren memiliki elemen yang telah dijabarkan, hal ini juga tergantung pada bentuk dari pesantren itu sendiri. Dhofier dalam Hamid menjelaskan bahwasannya bentuk pesantren jika dipandang dari keterbukaanya terhadap perubahan terbagi atas dua bentuk yaitu salafi dan khalafi (Hamid \& Kafi, 2017). Pesantren Khozinatul 'Ulum Blora sendiri merupakan pesantren yang tergolong khalafi dimana pesantren khalafi ialah pesantren yang menyelenggarakan kegiatan pendidikan dengan pendekatan modern melalui satuan pendidikan formal baik dengan pendekatan klasik ataupun modern (Maimun, 2017). Bahkan di Pesantren Khozinatul 'Ulum Blora sudah dilengkapi dengan perguruan tinggi. Pemahaman mengenai elemen yang terdapat dalam pesantren ini akan mempermudah dalam mencari dan menganalisis potensi yang terdapat di masing-masing komponen yang bisa dikembangkan oleh pemimpin pesantren.

\section{METODE PENELITIAN}

Penelitian ini merupakan penelitian kualitatif deskriptif, yaitu di dasarkan pada fenomena yang terjadi di pesantren Khozinatul 'Ulum Blora. Pengumpulan data dilakukan dengan teknik wawancara, observasi dan juga dokumentasi secara langsung oleh peneliti (Ikhwan, 2021). wawancara dilakukan kepada KH. A Zaki Fuad S.H.I sebagai wakil pengasuh dan juga KH Nur Rohim, S.Pd sebagai pembina.

Analisis data dilakukan dengan menggunakan teori Miles and Huberman yaitu pengumpulan data, reduksi data, display data, dan verifikasi data yang di dapatkan di pesantren Khozinatul 'Ulum Blora. alasan pesantren ini digunakan sebagai lokasi penelitian ialah karena pesantren Khozinatul 'Ulum Blora merupakan pesantren terbesar di kabupaten Blora dengan empat pesantren cabang dimana selain pesantren Khozinatul 'Ulum pusat terdapat, Khozinatul 'Ulum Al Azhar, Khozinatul 'Ulum An-Nada, Khozinatul 'Ulum Al Mubarok, Khozinatul 'Ulum AnNawa. 


\section{TEMUAN DAN PEMBAHASAN}

\section{Pesantren Khozinatul 'Ulum Blora}

Pesantren Khozinatul 'Ulum Blora merupakan pesantren yang terletak di Jl. Mr Iskandar, No. XII/2, Mlangsen, Kec. Blora Kota, Kab. Blora, Jawa Tengah. Pengasuh pesantren ini ialah KH Muharror Ali beserta Hj Umi Hani. Jika dilihat dari sisi materi yang diajarkan di pesantren ini, pesantren ini memiliki perpaduan antara kitab dan juga Al-Qur'an. Namun, dominasi yang diberikan dalam Pesantren Khozinatul 'Ulum Blora ialah kitab yaitu kitab kuning atau kitab klasik yang diberikan dengan model pembelajaran bandongan, sorogan, hafalan, dan klasikal. Sedangkan dalam pembelajaran Al-Qur'an Pesantren Khozinatul 'Ulum Blora menerapkan metode pembelajaran hafalan, setoran baik binnadzhar ataupun hafalan dan juga dengan metode diklat.

Berdirinya suatu lembaga pendidikan tidak lepas dari visi yang ingin di gapai beserta misi dalam upaya menggapai visi tersebut. Visi Pesantren Khozinatul 'Ulum Blora yaitu Menjadi lembaga dakwah, lembaga pendidikan Islam dan sosial yang unggul serta terkemuka dalam mencerahkan dan mencerdaskan kehidupan berbangsa, guna mempersiapkan generasi bangsa yang unggul, sholih, mulia, berilmu tinggi serta ber-akhlaqul karimah. Demi menggapai visi ini terdapat lima misi yang dilakukan, yaitu: 1) Membina dan mengembangkan dakwah dan pendidikan Islam yang seluas-luasnya dengan semangat khidmah dan mauidzoh hasanah. 2) Mengawal, membela dan melestarikan akidah dan nilai-nilai Islam ahlusunnah wal jama'ah. 3) Menumbuhkan, mengembangkan dan menegakkan nilai-nilai kemanusiaan sesuai ajaran Islam ke arah kematangan berpikir, berakhlak mulia dan integritas sosial yang tinggi serta memiliki kepribadian yang unggul. 4) Meningkatkan kualitas SDM guna mampu mendalami, menghayati, mengamalkan dan mengembangkan Islam secara utuh serta mampu mengelola lingkungan. 5) Menanamkan dan menumbuhkembangkan nilai-nilai ketakwaan dan akhlak yang luhur, sehingga menjadi generasi bangsa yang unggul, sholih, mulia dan ber-akhlaqul karimah (Adib, 2021b).

Genealogi intelektual KH Muharror Ali jika dilihat dari sisi keilmuan AlQur'annya di dapatkan dari Pondok Pesantren Yanbu'ul Qur'an Kudus atas asuhan 
KH Arwani Amin. Sedangkan dalam sisi pendidikan kitab di dapatkan di Pesantren Maslakul Huda yang diasuh oleh KH Sahal Mahfudz. Selain belajar di pesantren ini KH Muharror Ali juga menempuh pendidikan formal di Perguruan Islam Matholi'ul Falah Kajen, nantinya sistem pembelajaran di Perguruan Islam Matholi'ul Falah Kajen diadobsi dan menjadi kurikulum terpadu yang diterapkan di Pesantren Khozinatul 'Ulum Blora (TIM Publikasi, 2021).

KH Muharror Ali dalam mengelola Pesantren Khozinatul 'Ulum Blora dibantu dengan putra putrinya yaitu KH Ahmad Zaki Fuad, KH A Labib Hilmy, KH Fahim Mulabby, Hj Nur Hilwa Layyina, Hj Mil'ul Hana, Hj Muhim Nailul Ulya, Neng Malih Muyyada, dan Neng Mazid Ilma Rofida. Selain itu terdapat beberapa dewan pembina yang merupakan ustadz yang ikut dalam membimbing santri baik dari pondok, madrasah diniyyah ataupun madrasah formal.

Sebagai salah satu pesantren terbesar di Kabupaten Blora, Pesantren Khozinatul 'Ulum Blora memiliki lembaga pendidikan mulai dari formal dan juga non formal. Jenjang pendidikan formal dimulai dari tingkat PAUD, MI, MTs-SMP IP, MA dan juga Perguruan Tinggi. Sedangkan dalam jenjang pendidikan non formal dimulai dari tingkat Awwaliyah, Wustha dan juga 'Ulya dimana dalam jenjang pendidikan MTs dan MA diintegrasikan dengan Wustha dan 'Ulya (TIM Publikasi, 2021).

Suatu lembaga pendidikan pasti memiliki beberapa sumber pelajaran yang digunakan, jika di suatu pesantren biasanya memiliki sumber rujukan utama yaitu kitab kuning. Kitab yang digunakan di Pesantren Khozinatul 'Ulum Blora yaitu Nashoihul ibad, Fathul Qorib, Safinatun Najah, Al-Iqna', Bidayatul Hidayah, Sullamut Taufiq, Riyadhus Sholihin, dan Jurumiah (Adib, 2021b). Kitab rujukan ini biasa dinamakan dengan kitab kuning yang mana term kitab kuning sendiri diartikan dengan sehimpunan buku yang berisi pelajaran agama Islam (dirasat Islamiyah) yang mencakup fikih, akidah, tasawuf, akhlak dan tata bahasa (Thoha \& Karim, 2018).

\section{Model kepemimpinan transformasional Pesantren Khozinatul 'Ulum}

Dasar pemaknaan dari kepemimpinan transformasional menurut James McGregor Burns ialah kemampuan pemimpin dalam memberdayakan 
komunitasnya untuk berkinerja tinggi melalui sentuhan persuasif, psikologis dan edukatif yaitu pendekatan manusiawi dari seorang pemimpin organsiasi (Sagala, 2000). Melalui hal ini bisa dijelaskan bahwasannya bentuk kepemimpinan transformasional dalam sebuah pesantren merupakan kemampuan kiai dalam memanfaatkan komponen pesantren baik itu dirinya sendiri, masjid, kitab kuning (kurikulum), pondok dan santri dengan cara mengajak, memotivasi dan mendidik demi mengoptimalkan komponen dan mencapai tujuan yang dirumuskan dimana dalam Pesantren Khozinatul 'Ulum Blora tujuannya yaitu terciptanya kemaslahatan masyarakat, bangsa dan bernegara yang harmonis, sejahtera, adil dan makmur berlandaskan nilai-nilai keIslaman guna mewujudkan kebahagiaan insan di dunia dan akhirat (TIM Publikasi, 2021). Upaya nyata dalam menggapai tujuan ini ialah dengan menerapkan kurikulum terpadu antara pesantren, madrasah diniyyah dan madrasah formal (Syam, 2017).

Hal ini sesuai dengan yang dijabarkan oleh KH A Zaki Fuad bahwasannya tujuan pesantren yaitu menciptakan santri yang membawa kemaslahatan bagi masyarakat, bangsa dan negara dengan menampilkan sikap yang harmonis, sejahtera, adil dan makmur sesuai dengan pendidikan Islam yang di dapatkan di pesantren agar tercapai kebahagiaan dunia dan akhirat (Fuad, 2021).

Analisis aktivitas yang dilakukan demi melaksanakan prinsip ini didasarkan pada prinsip kepemimpinan transformasional menurut hidayat di Pesantren Khozinatul 'Ulum Blora ialah (Hidayat, 2020): pertama, simplifikasi atau keterampilan kiai dalam mengungkapkan visi secara jelas. Visi yang terdapat dalam Pesantren Khozinatul 'Ulum Blora sudah sangat jelas dimana visinya yaitu menjadi lembaga dakwah, lembaga pendidikan Islam dan sosial yang unggul serta terkemuka dalam mencerahkan dan mencerdaskan kehidupan berbangsa, guna mempersiapkan generasi bangsa yang unggul, saleh, mulia, berilmu tinggi serta berakhlakul karimah (Ikhwan, 2019). Visi ini terpampang jelas dalam setiap aturan dan buku pedoman yang dimiliki oleh Pesantren Khozinatul 'Ulum Blora. Visi ini juga selalu ditekankan oleh kiai dalam setiap rapat bersama dengan berbagai lembaga pendidikan yang berhubungan dengan Pesantren Khozinatul 'Ulum Blora (Adib, 2021b). 
Kedua, motivasi yaitu kemampuan dalam memberikan energi kepada pengikutnya, lebih spesifik motivasi ini ialah motivasi kerja atau keadaan yang bisa menggerakkan manusia kearah tujuan tertentu (Susanto, 2017). Kiai dalam memberikan motivasi kepada para pembina, ustadz dan siswa dengan memberikan cerita perjuangan yang dialaminya ketika waktu muda, cerita ini disesuaikan dengan siapa yang dihadapi. Ketika berhadapan dengan santri maka cerita yang ditampilkan adalah perjuangan dalam mendapatkan pendidikan meskipun dalam himpitan ekonomi dengan tetap mempertahankan birrul walidain. kemudian ketika berhadapan kepada pembina dan ustadz, kiai menceritakan mengenai perjuangan dalam merintis pesantren dan juga keikhlasan dalam berjuang dimana ketika keikhlasan ini ada dalam setiap perjuangan menegakkan pesantren, maka akan membuahkan hasil baik di dunia ataupun di akhirat.

Dari hasil observasi aktivitas menceritakan perjuangan kiai ini diketahui ketika pelaksanaan haflah maulidiah ataupun akhirussanah (peringatan maulid nabi dan akhir tahun) ketika kiai diberikan kesempatan untuk memberikan sambutan dan juga ketika pengajian kitab tafsir jalalain yang dilaksanakan setiap ahad pagi (Adib, 2021a).

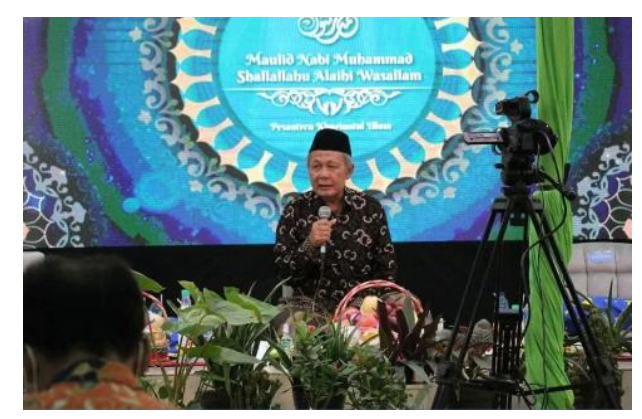

Gambar 1. Pidato Kiai dalam haflah maulidiyah

Ketiga, fasilitas, yaitu kemampuan dalam memfasilitas, sebagai lembaga pendidikan kholaf fasilitas yang diberikan kiai baik kepada santri ataupun kepada ustadz sudah sangat baik dimana bagi santri demi menjadikan dirinya sebagai manusia unggul dalam budi, ilmu dan agama disediakan pondok yang layak, perpustakaan yang memadai dan berbagai unit pengembangan bakat seperti pengolahan sampah, desain grafis, elektronika, menjahit dan berbagai seni islami. Sedangkan bagi ustadz selain diberikan ruangan yang memadai juga terdapat 
workshop dan seminar setiap akhir tahun dan semester guna meningkatkan kompetensinya dalam membimbing santri.

Hal ini sesuai dengan hasil observasi yang dilakukan bahwasannya pesantren Khozinatul 'ulum Blora memiliki beberapa lembaga pengembangan bagi santri baik perpustakaan dan pengembangan kompetensi berupa pelatihan desain dan lainnya (Adib, 2021a). Selain itu K Nur Rokhim juga menjelaskan bahwasannya dilaksanakan Workshop dan seminar setiap akhir tahun yang pelaksanaannya berbarengan dengan aktivitas evaluasi tahunan seluruh lembaga di yayasan (Rohim, 2021).

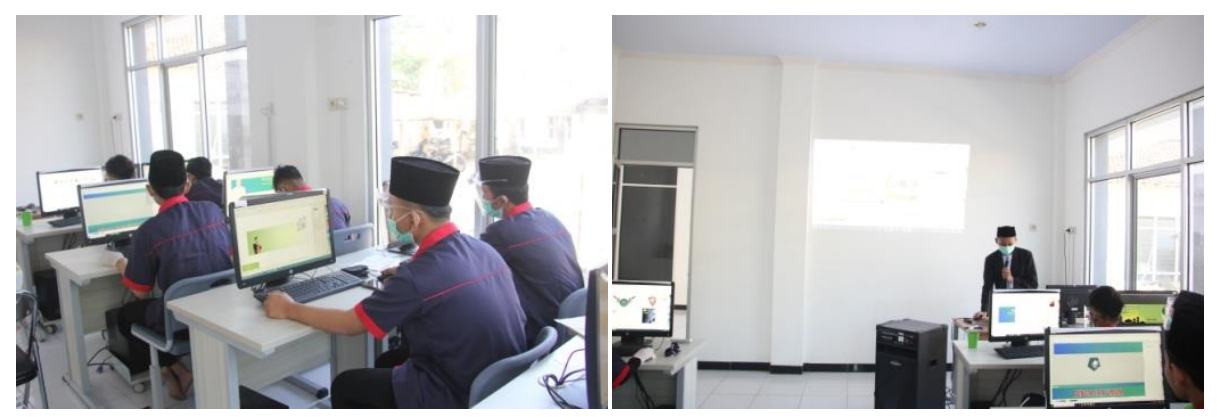

Gambar 2. Pelatihan desain

Keempat, inovasi, yaitu kemampuan untuk berani dan bertanggung jawab melakukan perubahan. Inovasi yang dilakukan di pesantren khozinatul 'ulum blora salah satunya adalah dengan dirubahnya kurikulum mandiri menjadi kurikulum terpadu. Kurikulum ini memadukan pesantren, lembaga pendidikan formal dan non formal menjadi satu kesatuan di bawah kurikulum yang sama. Kurikulum ini merupakan adobsi dari Perguruan Islam Matholi'ul Falah Kajen sebagai role model pendidikan Islam yang dirasa berhasil dalam mencetak kader unggul sesuai dengan visi yang telah ditetapkan. Selain itu demi menciptakan santri yang memiliki kompetensi di bidang desain, pesantren juga bekerjasama dengan kementrian ketenagakerjaan dalam menciptakan BLK (Balai Latihan Kerja) Komunitas yang diselenggarakan di Pesantren Khozinatul 'Ulum Blora dan ajakan dari Indomart dalam upaya pemberdayaan ekonomi pesantren. Hal ini sekaligus mejelaskan bahwasannya kiai memiliki pemikiran yang terbuka akan paradigma positif lainnya.

Hal ini disampaikan oleh KH A Zaki Fuad yang menyatakan bahwasannya demi meningkatkan kualitas santri pesantren berinovasi dalam melakukan 
perombakan kurikulum. Perombakan ini tidak asal namun diawali dengan studi banding ke lembaga yang menjadi acuan dalam perubahan kurikulm yaitu Perguruan Islam Matholi'ul Falah Kajen (Fuad, 2021). Pernyataan yang serupa juga disampaikan oleh K Nur Rokhim bahwasannya perubahan kurikulum menjadi kurikulum terpadu diawali dengan studi banding kemudian dilanjutkan dengan rapat penyusunan kurikulum dan kemudian di terapkan serta di evaluasi (Rohim, 2021).

Kelima, mobilitas, yaitu optimalisasi sumber daya dalam mencapai visi. Optimaliasai komponen pesantren dilaksanakan dengan memberikan pembagian kerja secara sistematis sesuai dengan tugas dan tanggung jawab setiap komponen yang terdapat di Pesantren Khozinatul 'Ulum Blora. keenam, tekad, yaitu tekad kuat untuk menyelesaikan dengan baik dan tuntas. Kebulatan tekat pemimpin dapat diketahui dengan selalu dilakukannya evaluasi baik terjadwal ataupun insidental. Evaluasi terjadwal dilakukan setiap empat bulan sekali untuk mengetahui sejauh mana ketercapaian kinerja yang dilakukan oleh pengurus dan ustadz dan juga untuk mencari solusi mengenai permasalahan yang di timbulkan dalam pelaksanaan kegiatan Pesantren Khozinatul 'Ulum Blora.

Hal ini sesuai dengan yang dijelaskan oleh K Nur Rokhim bahwasannya evaluasi dalam semua kegiatan dilaksankaan setiap empat bulan sekali. Selain itu terdapat evaluasi yang dilakukan ketika terdapat kegiatan yang memerlukan saat itu juga untuk dilaksanakan evaluasi (Rohim, 2021).

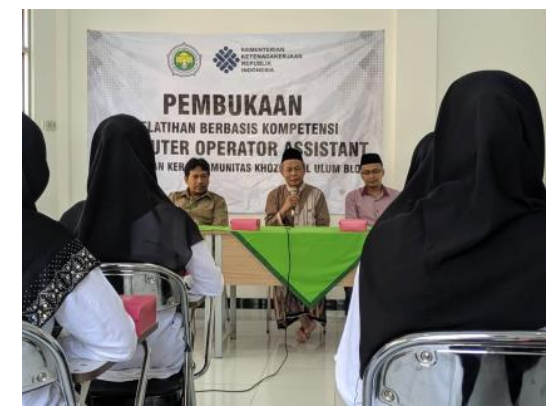

Gambar 3. Pelatihan peningkatan kompetensi pendidik 


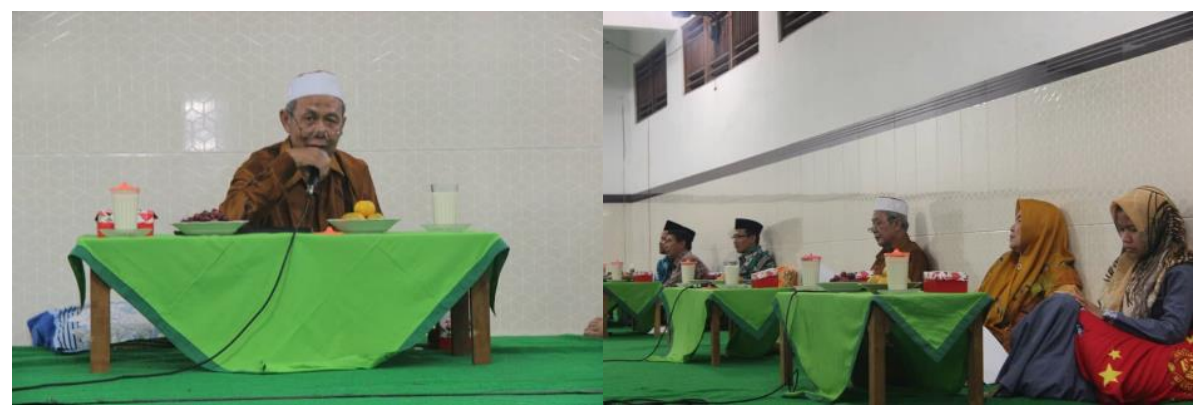

Gambar 5. Evaluasi 4 Bulan Sekali

\section{KESIMPULAN}

Kepemimpinan Transformasional di Pesantren Khozinatul 'Ulum Blora terlihat melalui prinsip yang dijadikan sebagai dasar pelaksanaanya. Terjaganya prinsip dalam kepemimpinan transformasional ini memberikan pengaruh yang baik dalam upaya mencapai tujuan pesantren yang sudah di tetapkan.

Prinsip dasar dalam kepemimpinan transformasional di Pesantren Khozinatul Ulum Blora yaitu: pertama, simplifikasi diperlihatkan dengan sudah jelasnya visi Pesantren Khozinatul 'Ulum Blora. kedua, motivasi yaitu kiai dalam memotivasi ustadz dan santri sesuai dengan tanggung jawab masing-masing. ketiga, fasilitas, yaitu memberikan fasilitas baik fisik ataupun akademik kepada santri dan juga guru. keempat, inovasi, yaitu berani dan bertanggung jawab dan terbuka akan hal baru dibuktikan dengan adanya perubahan kurikulum dan kerjasama dengan berbagai pihak atas intruksi kiai. kelima, mobilitas yaitu dengan melakukan pembagian kerja secara sistematis sesuai dengan tanggung jawab setiap komponen. keenam, tekad dibuktikan dengan evaluasi sebagai bentuk pengawalan dan perbaikan kegiatandi Pesantren Khozinatul 'Ulum Blora.

Guna meningkatkan kualitas kepemimpinan di Pesantren Khozinatul 'Ulum Blora diberikan beberapa saran. Bagi pimpinan yaitu konsistensi dan keterbukaan akan hal baru dalam hal pengembangan pesantren Khozinatul 'Ulum Blora. Bagi warga pesantren yaitu keaktivan dengan ikut serta dalam segala kegiatan yang di laksanakan di pesantren Khozinatul 'Ulum Blora 
55 JIE (Journal of Islamic Education)

e-ISSN: 2528-0465 (online) | Volume 7, Issue 1 | Mei 2022

p-ISSN: 2503-5363 (print)

\section{BIBLIOGRAFI}

[1] Adib, H. (2021a). Dokumentasi Pesantren Khozinatul 'Ulum Blora. Blora.

[2] Adib, H. (2021b). Observasi Pesantren Khozinatul 'Ulum Blora. Blora.

[3] Aini, N. K. (2019). Model Kepemimpinan Transformasional Pondok Pesantren. Jakad Media Publishing.

[4] Anggraini, Z. R., \& Anwar, S. (2021). The Effect of Habituation of Dhuha on the Religiosity of Santri. Eddukasi: Jurnal Pendidikan Islam, 9(2), 153-168.

[5] Fuad, A. Z. (2021). Wawancara Terpandu. Blora.

[6] Hamid, A., \& Kafi, F. A. (2017). PENDIDIKAN KARAKTER BERBASIS PESANTREN: Pelajar dan Santri dalam ERA IT dan Cyber Culture. Imtiyaz.

[7] Hidayat. (2020). KEPEMIMPINAN DAN SUPERVISI PENDIDIKAN. YPSIM Banten.

[8] Hutahayan, B. (2020). Kepemimpinan, Teori Dan Praktik. Deepublish.

[9] Ikhwan, A. (2019). At-Turats Public Relations in an Islamic Perspective; Implementation Study at Madrasah. At-Turats: Jurnal Pemikiran Pendidikan Is/am, 13(2), 105-117. https://doi.org/https://doi.org/10.24260/atturats.v13i2.996

[10] Ikhwan, A. (2021). Metode Penelitian Dasar (Mengenal Model Penelitian dan Sistematikanya). Tulungagung: STAI Muhammadiyah Tulungagung.

[11] Khasanah, U. (2019). KEPEMIMPINAN TRANSFORMASIONAL DALAM MANAJEMEN PENDIDIKAN ISLAM. Jakad Media Publishing.

[12] Maimun. (2017). SUPERIORITAS PESANTREN DALAM PENDIDIKAN KARAKTER. Duta Media Publishing.

[13] Purnomo, H. (2020). Kiai dan Ttransformasi Sosial: Dinamika Kiai Dalam Masyarakat. Absolute Media.

[14] Remiswal, Hasbi, F., \& Diani, Y. P. (2020). Model Kepemimpinan Di Pondok Pesantren. PRODU: Prokurasi Edukasi Jurnal Manajemen Pendidikan Islam, 2(1).

[15] Rohim, N. (2021). Wawancara Terpandu. Blora.

[16] Sagala. (2000). Administrasi Pendidikan Kontemporer. Bandung: Alfabeta.

[17] Sholihah, N., \& Rahma, R. A. (2020). Model Kepemimpinan Kolektif Pesantren Studi Kasus Pada Pesantren Al-Adzkiya'Nurus Shofa Karang Besuki Kecamatan Sukun Kabupaten Malang. Jurnal Pendidikan Nonformal, 15(2), 64-73.

[18] Susanto, Y. (2017). Peran Kepemimpinan dalam Pengelolaan Koperasi. Deepublish.

[19] Syam, A. R. (2017). Posisi Manajemen Kurikulum Dan Pembelajaran Dalam Pendidikan. Muaddib: Studi Kependidikan Dan Keislaman, 71), 33-46. 
[20] Takdir, M. (2018). Modernisasi Kurikulum Pesantren. IRCiSoD.

[21] Thoha, M., \& Karim, A. (2018). Kitab Kuning dan Dinamika Studi KeIslaman. Pamekasan: Duta Media Publishing.

[22] TIM Publikasi. (2021). Profil Pesantren Khozinatul 'Ulum.

[23] Umiarso. (2018). Kepemimpinan Transformasional Profetik Kajian Paradigmatik Ontos Integralistik Di Lembaga Pendidikan Islam. Jakarta: Kencana.

[24] Yasid, A. (2018). Paradigma Baru Pesantren. Ircisod. 